Вдовіна Олена Олександрівна кандидат наук 3 соціальних комунікацій, доцент кафедри українознавства, культури та документознавства, Національний університет «Полтавська політехніка імені Юрія Кондратюка», Першотравневий проспект 24, м.Полтава, 36011, тел.: (093) 455-09-89, e-mail: svitljahok@gmail.com, https://orcid.org/0000-0003$3770-125 \mathrm{X}$

Мізіна Ольга Іванівна кандидат філологічних наук, доцент, доцент кафедри українознавства, культури та документознавства, Національний університет «Полтавська політехніка імені Юрія Кондратюка», Першотравневий проспект 24, м. Полтава, 36011, тел.: (095) 095-46-64, e-mail: olamizina@gmail.com, https://orcid.org/0000-0002-1988-6353

\title{
ОСОБЛИВОСТІ МЕТОДОЛОГІЇ НАУКОВОГО ДОСЛІДЖЕННЯ ЕЛЕКТРОННОГО ДІЛОВОДСТВА В СУДОВИХ ОРГАНАХ ВЛАДИ
}

Анотація. Ефективний розвиток системи державного управління в Україні потребує сучасних підходів до організації діяльності органів державної влади, покликаних реалізовувати державну політику в різних галузях господарського комплексу. Основна умова ухвалення управлінських рішень для якісної реалізації державної політики - достовірна та повна інформація щодо реального стану справ на місцях. Саме тому, нині актуальним $\epsilon$ питання оперативного отримання, аналізу та опрацювання інформації за допомогою сучасних інформаційних технологій (далі - IT) [1]. Використання IT у роботі усіх гілок влади, у тому числі й судової, стандартна практика чи не усіх європейських та світових країн. Судова система України, перебуваючи у стані тривалого реформування, переймаючи досвід та здобутки правотворчої та правозахисної діяльності зарубіжних країн, активно впроваджує системи електронного діловодства (далі - ЕД) у власну діяльність. Використання комплексних комп'ютерних інформаційних систем для здійснення ЕД який, у порівнянні з традиційним, паперовим, має значні переваги як-от: підвищення культури діловодства, економії коштів на тиражування та пересилання документації, зменшення часових витрат на вирішення завдань, пов'язаних з обслуговуванням громадян тощо, не лише сприяє налагодженню комунікацій між судами та громадянами, але й позитивно впливає на формування іміджу судової гілки влади у суспільстві. Саме тому, ЕД — це сучасний, інноваційний інструмент для підвищення ефективності роботи судових установ. Оскільки запорукою ефективної роботи судових органів $є$ вдало організована діяльність працівників апарату суду, доступ до інформаційних ресурсів та імплементація комп'ютерних діловодних систем в судах є важливим засобом підвищення результативності 
ïx роботи, а також прозорості й доступності для усіх учасників процесу. Зрештою, використання ЕД суттєво зменшує традиційний паперовий документообіг і можливість помилки в судовому діловодстві [2]. Всебічний аналіз питань, пов'язаних з різними аспектами діяльності судових органів влади в Україні, реалізується завдяки використанню наукових досліджень вітчизняних спеціалістів.

Ключові слова: електронне діловодство, суди, судові органи влади, методологія наукового дослідження, судочинні процеси.

Vdovina Olena Oleksandrivna $\mathrm{PhD}$ of Social Communication, Associate professor department of ukrainian studies, culture and documentation, National University «Yuri Kondratyuk Poltava Polytechnic», Pershotravnevyi Av. 24, Poltava, 36011, tel.: (093) 455-09-89, e-mail: svitljahok@gmail.com, https://orcid.org/0000-0003-3770-125X

Mizina Olha Ivanivna Ph.D. of Philological Sciences, Associate professor, Associate professor department of ukrainian studies, culture and documentation, National University «Yuri Kondratyuk Poltava Polytechnic», Pershotravnevyi Av. 24, Poltava, 36011, tel.: (095) 095-46-64, e-mail: olamizina@gmail.com, https://orcid.org/0000-0002-1988-6353

\section{FEATURES OF THE METHODOLOGY FOR THE SCIENTIFIC STUDY OF ELECTRONIC RECORDS MANAGEMENT IN THE JUDICIARY}

Abstract. The effective development of the system of public administration in Ukraine requires modern approaches to the organization of the activities of State authorities designed to implement State policy in various sectors of the economic complex. The main condition for making managerial decisions for the qualitative implementation of state policy is reliable and complete information on the real situation on the ground. That is why the issue of prompt acquisition, analysis and processing of information using modern information technologies (hereinafter - IT) is now relevant. The use of IT in the work of all branches of government, including judicial, is standard practice of almost all European and world countries. The judicial system of Ukraine, being in a state of long-term reform, adopting experience and achievements in law-making and human rights activities of foreign countries, is actively introducing electronic records management (ERM) into its own activities. The use of complex computer information systems for the implementation of the ERM, which, compared with traditional paper, has significant advantages: improving the culture of office management, saving money for the replication and transfer of documents, reducing the temporary costs of solving tasks related to the maintenance of citizens, etc., not only contributes to the establishment of communications between courts and citizens, but also positively affects the formation of the image of the judicial branch of government in society. That is why ERM is a modern, innovative tool for improving the efficiency of judicial institutions. Since the efficient functioning of the judiciary is ensured by 
the well-organized work of the court staff, access to information resources and the implementation of computer-based record-keeping systems in the courts is an important means of improving the efficiency of their work, as well as transparency and accessibility for all participants in the process. In the end, the use of ERM significantly reduces the traditional paper flow and the possibility of error in court proceedings. A comprehensive analysis of issues related to various aspects of the activities of the judicial authorities in Ukraine is carried out through the use of scientific research by domestic specialists.

Keywords: electronic records management, courts, judicial authorities, research methodology, litigation.

Постановка проблеми. Інтеграція України у європейське освітнє, наукове, правове та політичне співтовариство вимагає активної імплементації стандартів країн-членів Євросоюзу у вітчизняну практику. Не стало виключенням і судочинство, не лише як одна з трьох гілок влади, але й як інститут захисту прав та свобод людини і громадянина. Зростання з року в рік кількості справ у судах з однієї сторони та виникнення форс-мажорних обставин, у яких довелося працювати судовим інстанціям України та світу на протязі останнього року (пандемія Covid-19) з іншої - призводять до гострої необхідності подальшого розвитку судової системи у напрямі цифровізації судочинних процесів, яка полягає насамперед у переході до систем електронного діловодства, відмові (частковій або повній) від паперового документообігу, використанню систем електронної передачі, обробки, зберігання та архівування даних. Питання пошуку шляхів вдосконалення сучасних діловодних процесів у судах для оптимізації їх роботи, униможливлення заангажованості та упередженості, $є$ об'єктом наукових досліджень фахівців - правознавців, теоретиків і практиків юридичної сфери, спеціалістів суміжних галузей, аналітиків та науковців.

Аналіз останніх досліджень і публікацій. Питання використання інформаційних технологій в різноманітних сферах суспільного життя знаходяться в полі зору таких фахівців як М. Швець, В. Сльцов, М. Ясинок, В. Колісник, А. Агапов, А. Анісімов, Г. Атаманчук, Ю. Атаманова, О. Арсірій, О. Баранов, Ю. Батурін, І. Бачило, О. Дзьобань, В. Пилипчук [3]. Електронне судове діловодство, як складова частина електронного судочинства, представлене у науковому доробку М. Смирнова, В. Бринцева, В. Барбара, В. Смельянової, Н. Петухова, Н. Логінової, Р. Арсірія, Н. Кушакової-Костицької, А. Каламайка, М. Кравчика, Л. Сердюка, М. Бондаренка [4]. Водночас спостерігається брак праць, присвячених висвітленню методології наукового дослідження електронного діловодства в судових органах влади.

Мета статті - виявлення та аналіз особливостей методології наукового дослідження електронного діловодства в судових органах влади.

Виклад основного матеріалу. Основною формою пізнання реальної дійсності є наукове пізнання. Воно проходить цілеспрямовано, являє собою наукове дослідження, має певну природу, структуру й особливості. 
Результатом наукового пізнання виступає система понять, категорій, методологій, методів, законів, теорій. Головною метою наукового пізнання $є$ відкриття об'єктивної істини, що базується на конструктивно-критичному ставленні до дійсності. Основною функцією наукового пізнання $\epsilon$ обслуговування потреб практики. Наукове пізнання виступає як складний, суперечливий процес відтворення знань та здійснюється за допомогою різних методів дослідження, що $є$ певними способами, прийомами й процедурами, якими повинен володіти суб'єкт пізнання в процесі наукового дослідження.

Наукова методологія, як результат наукового пізнання, заснована на використанні таких критеріїв як:

1. системність знання,

2. формальна несуперечність,

3. перевірюваність,

4. відтворюваність,

5. відкритість для критики,

6. свобода від упередженості [5].

Варто зауважити, що у процесі роботи над дослідженням, науковець почергово проходить такі етапи ( див.рис.1):

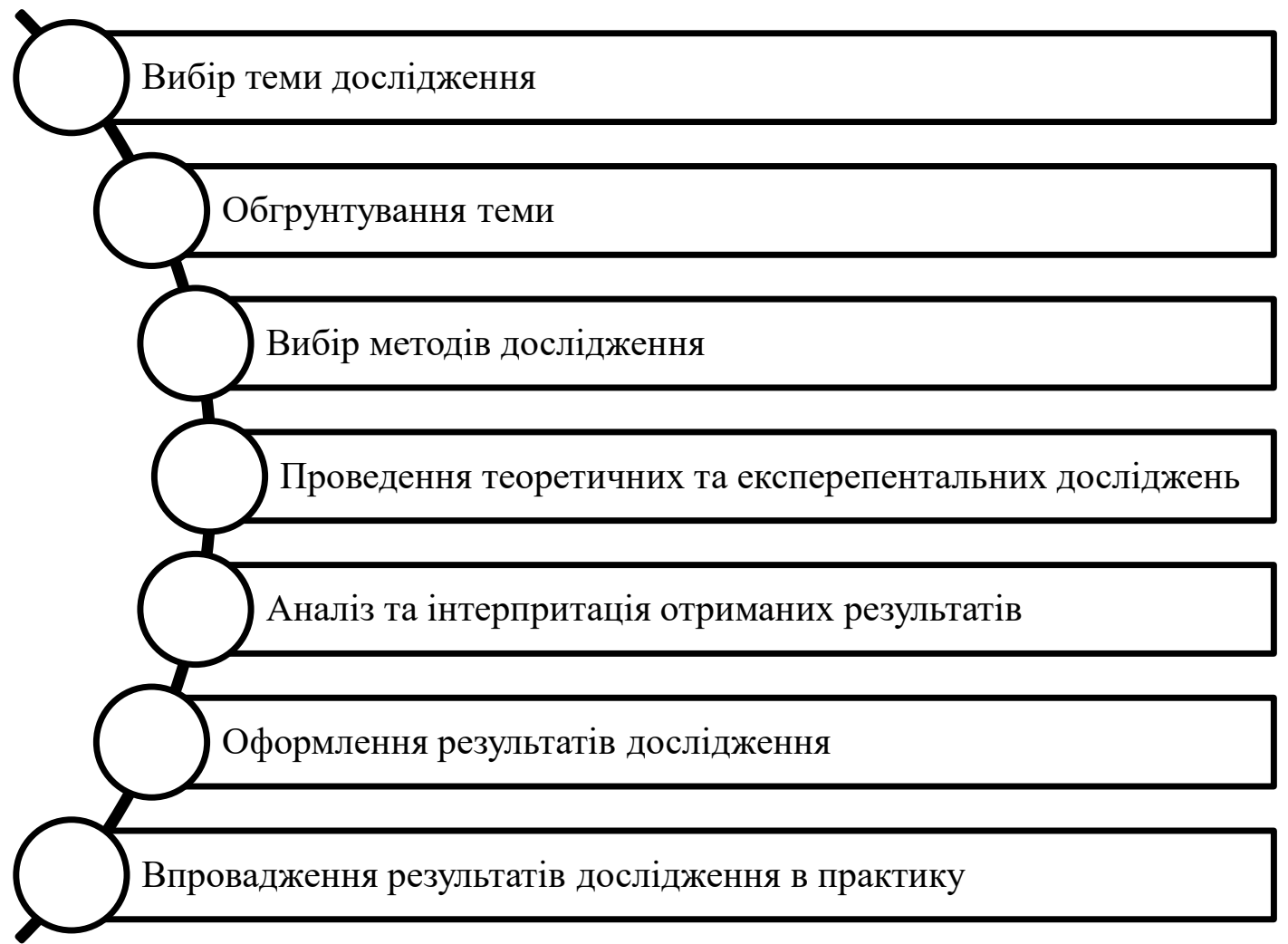

Pис.1 Етапи проведення наукового дослідження

Загалом, методологічні питання наукового дослідження можна представити у якості єдності таких складових як: мета, об єкт, предмет та метод. При проведенні наукового дослідження використовують методи, вибір яких залежить від мети і завдань дослідження [5]. Виділяють наукові та спеціальні наукові дослідження. До наукових належать (див.табл.1): 
Наукові методи дослідження

\begin{tabular}{|c|l|l|}
\hline №3/п & Група методів & Складові групи \\
\hline 1. & Загальнологічні & Аналіз, синтез, індукція, дедукція, аналогія. \\
\hline 2. & Емпіричні & $\begin{array}{l}\text { Спостереження, опис, порівняння, рахунок, } \\
\text { вимір, тестування, експеримент, моделювання. }\end{array}$ \\
\hline 3. & Теоретичні & $\begin{array}{l}\text { Аксіоматичний, гіпотетичний, формалізація, } \\
\text { абстрагування, ранжирування, узагальнення, } \\
\text { сходження від абстрактного до конкретного, } \\
\text { системний метод. }\end{array}$ \\
\hline
\end{tabular}

Дослідження особливостей електронного діловодства судових установ (далі - ЕДСУ) вимагає аналізувати базові методи й методичні підходи до вивчення передусім об'єкта дослідження. Важливою ланкою в логіці цього дослідження є термінологічний аналіз означеної предметної галузі. Варто зазначити, що судову владу в Україні відповідно до конституційних засад поділу влади здійснюють незалежні та безсторонні суди, утворені згідно 3 законом. Судочинство здійснюють Конституційний Суд України та суди загальної юрисдикції. Судочинство - це діяльність судової системи з розгляду цивільних та кримінальних справ; здійснюється на засадах рівності всіх учасників судового процесу перед законом і судом, законності, змагальності, диспозитивності, гласності й інших принців [6]. Суд, судова влада виникли та існують у суспільстві як об'єктивно необхідні для його нормального функціонування й розвитку інститути. Ефективність кожної судової системи значною мірою залежить від тих специфічних економічних, політичних, правових умов, в яких вона діє. Велику роль тут відіграють історичні умови ії формування, традиції, що склалися, правова культура. На становлення судової влади в Україні значною мірою впливала політична залежність від держав, до складу яких вона входила на різних етапах свого розвитку [7]. У ст. 6 Конституції України передбачається поділ державної влади України на три окремі гілки - законодавчу, виконавчу та судову, що відповідає принципам демократичної держави [ 8]. Суд вирізняється серед інших органів низкою ознак:

- розглядає і вирішує особливі категорії справ, які не може розглянути ніякий інший орган;

- його рішення проголошуються іменем України і $є$ обов'язковими для всіх громадян та органів, яким вони адресовані;

- справи розглядаються в суді 3 суворим дотриманням особливої процедури, що регламентуються виключно законами України;

- $є$ самостійним у розгляді справи (між судами немає відносин підлеглості) [9]. Конституційними принципами судочинства, що закріплені в ст. 126-129 Конституції України, є такі: законність; рівність усіх учасників судового процесу перед законом і судом; забезпечення доведеності вини; змагальність сторін і свобода в наданні ними суду своїх доказів і доведенні перед судом їх переконливості; підтримання державного обвинувачення в 
суді прокурором; забезпечення обвинуваченому права на захист; гласність судового процесу та його повне фіксування технічними засобами; незалежність i недоторканність суддів, їхнє підкорення тільки закону; незмінюваність суддів; колегіальний і одноособовий розгляд справ у суді; забезпечення апеляційного та касаційного оскарження рішення суду, крім випадків, встановлених законом; обов'язковість рішень суду. В ст. 129 Конституції України передбачається, що законом можуть визначатися й інші засади судочинства в судах окремих судових юрисдикцій [8].

Судочинство - це порядок судового розгляду кримінальних, цивільних та адміністративних справ. Розрізняють кримінальне, цивільне й адміністративне судочинство. Іншими словами, судочинство - це діяльність судової системи з розгляду цивільних, кримінальних, господарських справ та деяких категорій справ про адміністративні правопорушення. Судочинство в Україні здійснюється на засадах рівності всіх учасників судового процесу перед законом і судом, законності, змагальності, гласності та інших принципів [10]. Впровадження IT у судочинство потребує створення такого предметного інформаційного середовища, яке забезпечить суддю необхідними даними, мінімізує витрати його часу на технічну роботу, що в результаті сприятиме оперативності прийняття судових рішень. Інформаційне забезпечення судочинства має на меті надати судді в зручному режимі роботи структуровану систему даних і знань щодо кожної судової справи: законодавчі та відомчі нормативні акти; статистичні дані про розгляд справ у судах; матеріали узагальнення судової практики; інформаційні ресурси центральних органів державної влади; інформаційні ресурси органів внутрішніх справ України, прокуратури, інших інституцій, що беруть участь у кримінальному процесі; інформацію 3 міжнародного права. Враховуючи такі аспекти судочинства, як відкритість та прозорість, а також необхідність забезпечити право громадян України на інформацію, особливу увагу фахівці звертають на створення інформаційно-пошукових систем матеріалів судової практики. Створення таких систем, як i взагалі питання доступу до правосуддя, неодноразово висвітлювалося в документах Ради Свропи як одна 3 найважливіших умов справедливого застосування закону [11]. Визначаючи систему документації, що застосовується в судочинстві, як і в будь-якій іншій сфері, як сукупність пов'язаних документів, фахівці підкреслюють, що в діяльності суду використовуються дві такі системи, незалежні одна від одної. Перша пов'язана 3 процесуальною діяльністю 3 розгляду судових справ. Основні складові цієї системи передбачені процесуальними кодексами України та інструкціями 3 діловодства в судах. Друга - характерна усім підприємствам і установам організаційно-розпорядницька система документації, визначена прийнятими в державі стандартами й доповнена в кожній установі їі внутрішніми інструкціями.

Зазначимо, що впровадження електронного документообігу в судочинство має свої особливості й пов'язане 3 деякими проблемами. Наприклад, протокол допиту свідка (підозрюваного, затриманого) 
зобов'язані підписати слідчий та особа, що дає свідчення. Отже, щоб забезпечити юридичну силу такому документові, його необхідно оформлювати лише в паперовій формі. Триває переведення 3 паперового в електронний формат важливої для судів інформації, для чого потрібні фахівці-програмісти, здатні створити інформаційну технологію підтримки прийняття судового рішення як структурованої системи надання матеріалів справи, встановлення зв’язку між фактами, документами, що їх підтверджують, та висновками обвинувачення [12].

В межах судової системи та судочинства судове діловодство розглядається як сукупність процесів, які забезпечують документування управлінської інформації та організацію роботи зі службовими й іншими документами в судових установах. Необхідність належного діловодства та його вдосконалення зумовлені такими чинниками: ускладнення функцій державного управління, зокрема судових установ, підвищує вимоги до складання документів, їх оформлення та обробки; раціоналізація роботи 3 документами - важливий напрям підвищення ефективності управлінської праці, що дає змогу уникати невиправданих часових витрат, зосереджувати зусилля управлінців на оперативному й високоякісному вирішенні конкретних управлінських питань; забезпечення прав та інтересів громадян, які вступають у правовідносини з державними органами [13]. Виділяють такі аспекти діловодства:

1) юридичний - забезпечення законності та дисципліни в діловодстві, необхідності офіційно закріплювати вимоги, що ставляться до документів відповідними нормативно-правовими актами, і безумовного їх дотримання;

2) організаційний, який виявляється у налагодженні різноманітних i досить складних організаційних відносин, що виникають між органами державної влади, підприємствами, організаціями щодо створення документів, їх руху, обробки;

3) економічний, пов’язаний з економічною доцільністю, оптимальністю його здійснення [14].

Документування в державних органах управління - це регламентований запис інформації на різноманітних носіях за встановленими правилами, що забезпечує iї юридичну силу, та спрямований на збереження всієї документації, що стосується основних напрямів і процедур роботи органу державної влади й прийнятих рішень протягом такого часу, доки ця документація становить цінність. Документування передбачає дотримання встановлених правил запису інформації, що надає юридичної сили створюваним документам. Юридична сила - властивість офіційного документа, надана йому чинним законодавством, компетенцією органу, що його видав, і встановленим порядком його оформлення [14]. Кожен документ $\epsilon$ часткою системи вищого рівня і входить у відповідну систему документації як іiі елемент. Основне завдання діловодної служби - встановити єдиний порядок документування й роботи 3 документами на основі використання сучасних IKT, автоматизованої технології роботи 3 документами та скорочення кількості документів. Згідно 3 інструкціями по організації 
діловодства в судових органах, загальне керівництво судовою службою діловодства (або канцелярією) і поточний та оперативний контроль за всім станом діловодства в даній установі здійснює керівник цієї судової установи. Інструкції зазначають, що організація діловодства, а також методичне керівництво та контроль за постійним дотриманням заздалегідь установлених правил роботи з різними документами в окремих підрозділах судової установи покладені на керівників (чи заступників керівників) цих підрозділів, а також у цих процесах задіяні помічники й секретарі судів, діловоди та архівісти. Таким чином, електронне діловодство та документообіг організовано в межах судочинства, під яким мається на увазі порядок судового розгляду справ або діяльність судової системи; $є$ поняттям конкретно-прикладним відносно понять «судова влада» і «суд».

Висновок. Підсумовуючи вище викладене можна зробити висновок, що в основі особливостей методології наукового дослідження електронного діловодства в судових органах влади покладені загальнонаукові й спеціальні наукові підходи [15]. Зокрема, термінологічний метод дає змогу уточнити понятійний апарат досліджуваної предметної галузі; системний - виявити сутність, ознаки, системні властивості об'єкта вивчення, фактори, що впливають на ефективність його функціонування; соціокомунікативний та інформаційний - виявити головні ознаки предмета дослідження. Таким чином, методологічна база сприяє формуванню системи поглядів на застосування IT у судових органах влади й створення електронного судового діловодства як цілісного комплексу теоретичних і прикладних складників.

\section{Лimepamypa:}

1. Вдовіна О.О. Використання електронного документообігу в системі судочинства України. URL: https://ic.ac.kharkov.ua/nauk_rob/nauk_vid/rio_old_2017/vh/v46/11.pdf (дата звернення 20.05.2021)

2. Матвієнко О. В. Основи організації електронного документообігу : навч. посіб. Київ : Центр учб. літ-ри, 2008.

3. Бринцев О. В. «Електронний суд» в Україні. Досвід та перспективи : монографія. Харків : Право, 2016. 72 с. Сер.: Інноваційне суспільство і розвиток законодавства.

4. Сердюк Л. Р. Теоретико-прикладні проблеми впровадження електронного судочинства в Україні. Наук. вісн. Ужгород. нац. ун-ту, 2016. Сер.: Право. Вип. 39. Т. 2. C. $115-118$.

5. Салига К.С. Методологія наукового дослідження економічної ефективності інвестицій в інноваційні проекти. URL: http://www.economy.nayka.com.ua/?op=1\&z=1791 ( дата звернення 20.05.2021)

6. Ядов В. А. Стратегия социологического исследования. Описание, объяснение, понимание социальной реальности. 3-е изд., испр. Москва : Омега-Л, 2007. 567 с.

7. Швець М. Системна інформатизація в правовій сфері. Вісн. Акад. прав. наук України. 2003. № 2 (33), 3 (34). С. 779-780.

8. Конституція України від 28 черв.1996 р., № 254к/96-ВР. Відом. Верховної Ради України. 1996. № 30. Ст. 141.

9. Закон України «Про судоустрій і статус суддів» від 7 лип. 2010 р. № 2453-VI. URL: https://tinyurl.com/y7y2h8p7 (дата звернення: 12.08.2016). 
10. Суд, правоохоронні та правозахисні органи України / В. С. Ковальський (кер. авт. кол.), В. Т. Білоус, С. Е. Демський та ін.; відп. ред. Я. Кондратьєв. Київ : Юрінком Інтер, 2002. $320 \mathrm{c}$.

11. Обрусна С. Зарубіжний досвід судового управління та можливості його використання при реформуванні судової системи України. Вісн. Вищ. ради юстиції. № 4. 2010. С. 52-71.

12. Никандров С. В. Электронные сетевые документы по технике: типология и ценностные свойства : автореф. дис. ... канд. пед. наук : 05.25.03. Санкт-Петербург, 2003. 20 с.

13. Малиновський В. Я. Державне управління. 2-ге вид., доповн. і переробл. Київ : Атіка, 2003. $576 \mathrm{c.}$

14. Малахов Е. В., Пелехов В. С. Организация систем автоматизированного документооборота. Тр. Одес. политехн. ун-та. 2006. Вып. 1 (25). URL: https://tinyurl.com/y9pl64hh (дата обращения: 20.05.2021).

15. Вдовіна О.О. Електронне діловодство як комунікаційна складова судочинства в Україні [Текст] : автореф. дис. ... канд. наук із соц. комунікацій : 27.00.02, 27 / Вдовіна Олена Олександрівна ; НАН України, Нац. б-ка України ім. В. І. Вернадського. Київ, 2018. - 17 с.

\section{References:}

1. Vdovina O.O. (2015). Vykorystannia elektronnoho dokumentoobihu v systemi sudochynstva Ukrainy [Use of electronic document management in the judicial system of Ukraine]. Visnyk Kharkivskoi derzhavnoi akademii kultury - Bulletin of the Kharkov State Academy of Culture, 46, 82-91. Retrieved from: https://ic.ac.kharkov.ua/nauk_rob/nauk_vid/ rio_old 2017/vh/v46/11.pdf [in Ukrainian].

2. Matviienko O. V., Tsivin M.N. (2008). Osnovy orhanizatsii elektronnoho dokumentoobihu [Fundamentals of Electronic Document Management]. Kyiv : Tsentr uchb. litry. Retrieved from: https://cul.com.ua/preview/Osnov_organ_elektronnogo_doumentoobigyMatvienko.pdf [in Ukrainian].

3. Bryntsev O. V. (2016). «Elektronnyi sud»v Ukraini. Dosvid ta perspektyvy ["Electronic Court" in Ukraine. Experiences and perspectives]. Kharkiv : Pravo [in Ukrainian].

4. Serdiuk L. R. (2016). Teoretyko-prykladni problemy vprovadzhennia elektronnoho sudochynstva $\mathrm{v}$ Ukraini [Theoretical and applied problems of introduction of electronic litigation in Ukraine]. Naukovyi visnyk Uzhhorodskoho natsionalnoho universytetu Scientific bulletin of Uzhgorod National University, 2, 115-118 [in Ukrainian].

5. Salyha K.S. (2013). Metodolohiia naukovoho doslidzhennia ekonomichnoi efektyvnosti investytsii $\mathrm{v}$ innovatsiini proekty [Methodology of scientific study of costeffectiveness of investments in innovative projects]. Elektronnyi zhurnal «Efektyvna ekonomika» - Electronic journal "Efficient Economy", 2, 43-47 Retrieved from: http://www.economy.nayka.com.ua/?op=1\&z=1791 [in Ukrainian].

6. Iadov V. A. (2007). Stratehyia sotsyolohycheskoho yssledovanyia [Strategy of sociological research. Description, explanation, understanding of social reality]. Moskva : Omeha-L [in Russian].

7. Shvets M. (2003). Systemna informatyzatsiia v pravovii sferi [System informatization in the legal sphere]. Visnyk akademii pravovykh nauk Ukrainy - Bulletin of the Academy of Legal Sciences of Ukraine, 2, 779-780 [in Ukrainian].

8. Konstytutsiia Ukrainy : vid 28.06.1996 No254k/96 -VR [The Constitution of Ukraine from 28.06.1996, No254k/96-VR]. zakon.rada.gov.ua. Retrieved from https://zakon.rada.gov.ua/laws/show/254\%D0\%BA/96-\%D0\%B2\%D1\%80\#Text [in Ukrainian].

9. Zakon Ukrainy Pro sudoustrii i status suddiv: pryiniatyi 2 cherv. 2016 roku No 2453-VI [Law of Ukraine on Judicial System and Status of Judges]. Retrieved from: https://tinyurl.com/y7y2h8p7 [in Ukrainian]. 
10. V. S. Kovalskyi (2002). Sud, pravookhoronni ta pravozakhysni orhany Ukrainy [Court, law enforcement and human rights bodies of Ukraine]. Kyiv : Yurinkom Inter. Retrieved from: https://lawbook.online/page/pravooxr/ist/ist-22--idz-ax293.html [in Ukrainian].

11. Obrusna S. (2010). Zarubizhnyi dosvid sudovoho upravlinnia ta mozhlyvosti yoho vykorystannia pry reformuvanni sudovoi systemy Ukrainy [Foreign experience of judicial administration and the possibility of its use in reforming the judicial system of Ukraine]. Visnyk Vyshchoi rady Yustytsii - Bulletin of the Supreme Council of Justice, 4, 52-71 [in Ukrainian].

12. Nikandrov S. V. (2003). Elektronnyie setevyie dokumentyi po tehnike: tipologiya i tsennostnyie svoystva [Electronic network documents on technology: typology and values]. Extended abstract of candidate's thesis. Sankt-Peterburg [in Russian].

13. Malynovskyi V. (2003). Derzhavne upravlinnia [Public administration]. Kyiv : Atika [in Ukrainian].

14. Malakhov E. V., Pelekhov V. S. (2006). Orhanyzatsyia system avtomatyzyrovannoho dokumentooborota [Organization of automated document management systems]. Trudy Odesskoho polytekhnycheskoho unyversyteta - Works of Odessa Polytechnic University, 1(25), 94-97. Retrieved from: https://tinyurl.com/y9pl64hh [in Ukrainian].

15. Vdovina O.O. (2018). Elektronne dilovodstvo yak komunikatsiina skladova sudochynstva $\mathrm{v}$ Ukraini [ Electronic record-keeping as a communication component of judicial proceedings in Ukraine]. Extended abstract of candidate's thesis.Candidate's thesis. NAN Ukrainy, Nats. b-ka Ukrainy im. V. I. Vernadskoho [in Ukrainian]. 